\title{
COW CLEANLINESS IN DAIRY HERDS WITH TIE STALL SYSTEMS IN BOSNIA AND HERZEGOVINA
}

\author{
Miljan ERBEZ ${ }^{1,2}$, Božo VAŽIĆ ${ }^{3}$, Biljana ROGIĆ ${ }^{3}$, Knut Egil BØE ${ }^{4}$, Lars Erik RUUD ${ }^{5}$
}

Received November 26, 2017; accepted May 31, 2018.

Delo je prispelo 26. novembra 2017, sprejeto 31. maja 2018.

\section{Cow cleanliness in dairy herds with tie stall systems in Bosnia and Herzegovina}

This study involved 70 tie stall dairy herds from all over Bosnia and Herzegovina. In each herd, trained observers scored the cleanliness (score $1=$ clean to score 4 = very dirty) of 5 randomly chosen cows, total 350 cows, on 5 different body parts (rear, thigh, leg, udder and belly). Total cleanliness score was calculated by adding together the scores for the different body parts. The observers also recorded data on stall design, flooring and use of bedding materials. The proportion of cows scored as dirty or very dirty (score 3 and 4 ) was $33.4 \%, 50.8 \%$, $55.1 \%, 16.0 \%$ and $18.6 \%$ for the legs, thighs, rear, udder and belly respectively. $57.4 \%$ of the cows got a total cleanliness score $>10$. The mean total cleanliness score on herd level varied from 5.2 to 18.8. Tests of each stall design variable showed that tying system $(p<0.05)$, presence of stall dividers $(p<0.05)$ and manure system $(p<0.05)$ had a significant effect on total cow cleanliness, the use of bedding material $(p>0.15)$ and floor type $(p>0.15)$ had smaller effect. However, only the presence of stall dividers showed significant association to total cleanliness score in the full statistical model $(p<0.05)$.

Key words: cattle; dairy cows; housing; tie stalls; cleanliness; Bosnia and Herzegovina

\section{INTRODUCTION}

The dairy sector in Bosnia and Herzegovina (BiH) is mainly based on small-scale farms with $75.8 \%$ of the dairy herds being smaller than five dairy cows (FAO, 2012; Glavić et al., 2017). Jovović et al. (2014) found

\section{Čistoča krav $v$ čredah krav molznic $z$ vezano rejo $v$ Bosni in Hercegovini}

V študijo je bilo vključenih 70 čred krav molznic $\mathrm{z}$ vezano rejo v Bosni in Hercegovini. Čistost krav v vsaki čredi so ocenili usposobljeni opazovalci (ocena od 1 do 4, 1 = čisto, $4=$ zelo umazano) na osnovi petih naključno izbranih krav. Skupaj so pri 350 kravah ocenili čistost na petih različnih delih telesa (zadnjica, stegna, noge, vime in trebuh). Skupno čistočo smo ocenili s seštevanjem ocen za različne dele telesa. Opazovalci so zabeležili tudi podatke o tipu stojišč, vrsti tal in o uporabi materialov za nastil. Delež krav, ki so bile ocenjene kot umazane ali zelo umazane (oceni 3 in 4), je bil 33,4 \% za čistost nog, $50,8 \%$ za stegna, $55,1 \%$ za zadnjico, $16,0 \%$ za vime in $18,6 \%$ za trebuh. Skupno oceno za čistost $>10$ je dobilo $57,4 \%$ krav. Povprečna skupna čistost na ravni črede je bila od 5,2 do 18,8. Analiza različnih tipov reje je pokazala, da so način privezovanja $(p<0,05)$, razdelilne ograje $(p<0,05)$ in sistem odstranjevanja gnoja $(p<0,05)$ pomembno vplivali na čistočo krav, v manjši meri pa vrsta nastila $(p>0,15)$ in vrsta tal $(p>0,15)$. $\mathrm{V}$ skupnem statističnem modelu je samo prisotnost razdelilnih ograj pokazala statistično značilno $(p<0,05)$ povezavo s skupno oceno čistosti živali.

Ključne besede: govedo; krave; molznice; uhlevitev; vezana reja; čistoča; Bosna in Hercegovina

that $80 \%$ of the dairy herds in the lowland region and all dairy herds in the mountainous regions of Bosnia and Herzegovina were tie-stall housed. This is similar to the situation found in some EU countries, e.g. in Austria, approximately $18 \%$ of dairy farms provide loosehousing whereas $82 \%$ use a tethered husbandry system

\footnotetext{
1 Ministry of Agriculture, Forestry and Water management of Republic of Srpska, Department of Livestock Production, Banja Luka, RS, Bosnia-Herzegovina

2 Corresponding author, e-mail: miljanerbez@gmail.com

3 University of Banja Luka, Faculty of Agriculture, Banja Luka, RS, Bosnia-Herzegovina

4 Norwegian University of Life Science, Faculty of Veterinary Medicine and Biosciences, Campus Ås, Ås, Norway

5 Inland Norway University of Applied Sciences, Faculty of Applied Ecology, Agricultural Sciences and Biotechnology, Elverum, Norway
} 
(DG SANTE, 2017). Moreover, in Europe between $20 \%$ (lowland) and $80 \%$ (upland) of the cows are tethered at least in the winter (Popescu et al., 2013). In general, cow cleanliness is important for udder health (e.g. Schreiner and Ruegg, 2003), milk quality (Reneau et al., 2005; Neja et al., 2016), claw health (Bergsten and Pettersson, 1992), meat hygiene at slaughter (e.g. Hauge et al., 2012), animal welfare as well as the work load to remove manure. Cleanliness of the cows seems to be a larger challenge in tie-stall systems than in free walking systems for dairy cows (Herlin et al., 1994; Neja et al., 2016). Several stall design and management factors have been found to influence on cow cleanliness. The cleanliness is better on long standings compared to short standings (Nygaard, 1979; Gjestang, 1980), but Gjestang (1980) also found that stall length did not have a large impact on cow cleanliness as long as the stall length was within a recommended range (minimum length for short standings: 1,7 m). Zurbrigg et al. (2005) however, found that cow cleanliness was improved when the stall length was longer, and argue that shorter stalls forces cows to utilize the diagonal as this will be the longest distance available in a stall. However, even though stall dividers are recommended (e.g. Agriculture Canada, 1981; EFSA, 2009; Ruud et al., 2015) and commonly used, only one study was found focusing on the effect of stall dividers, and actually no effect on cow cleanliness was found (Nygaard, 1979).

According to Zurbrigg et al. (2005) increasing the tie-rail height is often anecdotally associated with overall dirtier cows, but in their study the proportion of cows with clean udders actually increased with increased tierail height.

One apparently important management factor for cow cleanliness is the use of bedding material, and Nygaard (1979) found a positive effect of increasing the amount of bedding material on cow cleanliness. Strangely, there seem to be no investigations focusing on effects of frequency (number per day) of cleaning the stall floor. Hultgren and Bergsten (2001) studied the effect of a rubber-slatted flooring system in the stalls, and found that cow cleanliness was significantly improved. Several investigations show that limitations in free movements, e.g. by using electrical cow trainers, improves cow cleanliness in tie stalls (Nygaard, 1979; Bergsten and Pettersson, 1992). Cow trainers are, however, not allowed in $\mathrm{BiH}$ due to animal welfare reasons (Official Gazzette of $\mathrm{BiH}$ no. 25/09). The aim of this study was to describe cow cleanliness and use of bedding in dairy herds with tie stalls in Bosnia and Herzegovina, and to examine effects of stall design on cow cleanliness.

\section{MATERIALS AND METHODS}

\subsection{SELECTION OF HERDS}

A total of 70 dairy herds with tie-stall systems from 16 municipalities all over $\mathrm{BiH}$ were randomly selected from the Register of agricultural producer's database (www.apif.net). Thirty of the herds were selected from geographical areas that were located lower than 300 meters above sea level and 40 herds were selected from geographical areas located higher than 600 meters above sea level. The main breeds in the study were Simmental (42 herds), Gatacko cattle (27 herds) and Holstein (1 herd). Gatacko is a local breed originated by crossbreeding of the autochthonous Busa cows and imported bulls of Tyrolean Grauvieh. It has a body weight of 450-500 kg, whereas mean height at withers is approx. $124 \mathrm{~cm}$ (Rogić et al., 2011). Body weight for Simmental and Holstein cows is normally between 600 and $750 \mathrm{~kg}$ and with mean height ranging from $142 \mathrm{~cm}$ for Simmental up to $150 \mathrm{~cm}$ for Holstein cows (Official Gazzete of RS, 2016). The mean herd size was $13.6 \pm 10.6$ dairy cows (mean \pm SD), ranging from 4 to 74 dairy cows. Mean grazing period for all farms was 5.7 months, three herds had 11 months grazing period and 16 herds practiced zero-grazing.

Cleaning of the stalls was performed manually in all herds, normally two times per day.

\subsection{STALL DESIGN AND USE OF BEDDING}

During the indoor feeding period from December 2013 to March 2014, a team of three trained observers visited all of the 70 dairy herds once at daytime, typically 1 hour after morning milking. A systematic protocol, adapted from Simensen et al. (2010), was used to record data on stall design, flooring, use of bedding material, stall cleanliness, cow cleanliness and type of housing on each farm. In most of the herds the stall equipment was homemade and not standardized. Because of the limited standardization of stalls, no observations of stall length and width were performed. The height of the stall front and the height of the feed bunk barrier were, however, measured. The presence of stall dividers (no stall dividers, stall dividers between every second stall or between each stall) and type of stall divider if any (short divider: $<$ half cow body length, long divider: > half cow body length) was recorded. Tying system was categorized as either chain or Grabner tie (a chain fixed vertically with an attached sliding frame around the cow's neck). Flooring categories were wood, concrete or rubber mats. Manure systems were categorized either as an open gutter, gutter covered with slatted floor or "traditional" (more or less a 
flat floor continuing backward from the stall base). Type of bedding, if present, were recorded as straw or sawdust, whereas the amount of bedding was recorded by simply measuring the depth of the bedding $(\mathrm{mm})$ at an approximate location of the cow's udder.

\subsection{OBSERVATIONS ON COW CLEANLINESS}

On each farm, five dairy cows were subjected to cleanliness observations. The cows were randomly chosen by selecting every, every second, every third cow etc., depending on the herd size. In one herd with only four dairy cows, a heifer was included to achieve data from five animals in all herds. Cow cleanliness was hence scored for a total of 350 dairy cows in the 70 herds following a scheme adapted from Schreiner and Ruegg (2003) and Ruud et al. (2010) by using a four point scale; $1=$ clean, $2=$ some dirt, 3 = dirty or $4=$ very dirty with caked-on dirt. The left and right side of the udder, thigh, leg, and belly were scored separately and the mean of the scores were used in the further analysis, whereas the rear part of the cow was given only one score (Figure 1). The rear part of the udder was scored together with the udder.

Total cleanliness score was calculated per cow by adding together the scores for the different body parts. Hence, a score of 5 indicated a totally clean cow and a score of 20 indicated a cow totally covered with dirt. Overall scores $>12.5$ will represent the dirty end of the scale (unacceptable dirty).

\subsection{STATISTICAL ANALYSIS}

For the statistical analyses, herd was the statistical unit. Based on the recorded data from the individual animals and housing charactristics, herd means were first calculated and then used in the analyses.

The effect of each stall design variable on overall cow cleanliness was analysed using one-way analysis of variance (ANOVA) or a Student-t test.

Two separate backward GLM procedure models were run in the programme XLSTAT 2016 (Addinsoft, 2016) with thigh cleanliness and overall cleanliness of the cow, as dependent variables, respectively. Thigh cleanliness was tested because it is the body part with the highest correlation for cleanliness across all body parts. The independent variables in both models were divider presence, divider style, tying system, manure system, flooring type, bedding type and bedding amount. The independent parameters that showed the least significant association to cleanliness were removed from the statistical analyses one by one, and the models were re-run until only significant $(p<0.05)$ variables remained.

Thigh cleanliness and overall cleanliness were tested in the same basic model:

$$
\begin{aligned}
\mathrm{Y}= & \mu+\text { DIVIDER }_{\text {presence }}+\text { DIVIDER }_{\text {style }}+\text { TYING }_{\text {system }} \\
& + \text { MANURE }_{\text {system }}+\text { FLOOR }_{\text {type }}+\text { BEDDING }_{\text {type }}+ \\
& \text { BEDDING }_{\text {amount }}
\end{aligned}
$$

\begin{tabular}{|l|c|c|c|c|}
\hline $\begin{array}{l}\text { Cow cleanliness } \\
\text { score }\end{array}$ & 1 (clean) & 2(some dirt) & 3 (dirty) & 4 (very dirty) \\
\hline Rear & & & \\
\hline Thigh & & & \\
\hline Leg & & & \\
\hline Bdder & & & \\
\hline
\end{tabular}

Figure 1: Scheme for cow cleanliness scoring on the rear, thigh, leg, udder and belly, where $1=$ clean, $2=$ some dirt, $3=$ dirty and $4=$ very dirty, adapted from Schreiner and Ruegg (2003) and Ruud et al. (2010) 


\section{RESULTS}

\subsection{COW CLEANLINESS}

More than $50 \%$ of the cows were scored as clean (score 1) on the udder and belly (Table 1), whereas only $23.4 \%$ of the cows were scored as clean on the legs, $18.9 \%$ on the thighs and $14.6 \%$ on the rear body part. However, a large proportion of the cows were scored as dirty (score 3 ) or very dirty (score 4$)$ on the thigs (50.8\%) and on the rear body part (55.1\%).

Seventeen cows (4.9\%) got atotally cleanliness score of 5 (totally clean whereas $42.6 \%$ of the cows got a score of $<10,33.1 \%$ got a score of 10 to 15 and $24.3 \%$ got a score of $>15$.

There was a large variation between herds regarding cow cleanliness, especially for the thigh, leg and rear part of the body (Table 1).

The mean total cleanliness score at herd level was $11.5 \pm 3.19$, and varied from 5.2 to 18.8 . Further, the total cleanliness score at herd level were $<10$ for $34.3 \%$ of the herds, $51.4 \%$ of the herds scored between 10 and 15 , and the remaining $14.3 \%$ of the herds scored $>15$.

\subsection{HOUSING AND MANAGEMENT VARIABLES}

In $55.7 \%$ of the herds, a tie chain (or even rope) was used for tying the cows, whereas $44.3 \%$ of the herds had a Grabner tie system (Table 2). The mean total height of the stall front was $1.44 \mathrm{~m}$ (range 1.12-1.80 m) and the mean height of the feed bunk barrier was $0.45 \mathrm{~m}$ (range $0.04-0.83 \mathrm{~m}$ ). In nearly half of the herds $(42.9 \%)$ there were no stall dividers, in $42.9 \%$ of the herds there were stall dividers between every stall and in the remaining $14.3 \%$ of the herds there were stall dividers between every second stall. Further, in the herds using stall dividers, $80 \%$ of the herds had short stall dividers and $20 \%$ of the herds had long stall dividers. The majority of the herds $(67.1 \%)$ had concrete stall flooring, whereas the rest of the herds had rubber mats or stall floors made of wood. In more than half of the herds, no bedding was used in the stalls, $42.9 \%$ of the herds used straw and, in the remaining $7.1 \%$ of the herds sawdust was used. In the herds that applied bedding material on the stall floor, the amount of bedding was quite limited (straw: mean $19.6 \mathrm{~mm}$, range $5-53 \mathrm{~mm}$ and sawdust: mean $10.8 \mathrm{~mm}$, range $4-20 \mathrm{~mm}$ ). $42.8 \%$ of the herds had an open gutter behind the stalls, in $34.3 \%$ of the herds there was a gutter covered with slatted flooring and in the remaining $22.9 \%$ of the herds there was no gutter (traditional).

\subsection{EFFECT OF HOUSING VARIABLES ON CLEANLINESS}

In a direct comparison between cows tied in stalls using the Grabner's tying system and cows tied with chains (Table 2), the totalcleanliness score wassignificantly lower (cleaner cows) for Grabner's tie compared to cows tied with chains. No significant effects of stall front height or feed bunk barrier height on total cleanliness score were found. However, in a comparison between $25 \%$ of herds $(n=22)$ with the highest feed bunk barriers compared to $25 \%$ of herds with the lowest ones $(\mathrm{n}=22)$, a clear tendency $(p=0.06)$ for cleaner cows were found for herds with lower feed bunk barriers (total cleanliness score $=11.1$ ) compared to the higher ones (total cleanliness score $=12.9$ ). Total cleanliness score was found to be significantly lower in stalls with dividers compared to stalls without dividers (Table 2), however, the length of the stall divider was not found to have an influence on total cleanliness score. Neither the type of material used for the stall base, the use of bedding, nor the type of bedding were found to have an influence on total cleanliness score. Total cleanliness score was, however, found to be significantly lower in stalls with slatted flooring covering the gutter compared to the open gutter or no gutter (Table 2).

Table 1: Mean cleanliness (SD) and distribution of cleanliness scores (\%) for individual body parts (legs, thigh, rear, udder and belly) based on $n=350$ dairy cows from 70-tie stall dairy herds

\begin{tabular}{llllll}
\hline & & \multicolumn{2}{l}{ Cleanliness score } & & \\
\cline { 3 - 6 } & & Clean & & & Dery dirty \\
& Mean (SD) & $(1.0+1.5)$ & $(2.0+2.5)$ & $(3.0+3.5)$ & $(4)$ \\
\hline Leg & $2.4(0.71)$ & 23.5 & 43.1 & 22.0 & 11.4 \\
Thigh & $2.7(0.75)$ & 18.9 & 30.3 & 29.4 & 21.4 \\
Rear & $2.7(0.75)$ & 14.6 & 30.3 & 31.7 & 23.4 \\
Udder & $1.8(0.59)$ & 52.3 & 31.7 & 12.9 & 3.1 \\
Belly & $1.9(0.69)$ & 56.0 & 25.4 & 13.4 & 5.2 \\
\hline
\end{tabular}


Table 2: Effect of different stall design variables on total cleanliness score ( $n=70$ dairy herds)

\begin{tabular}{|c|c|c|c|}
\hline Detail & Proportion and number of herds & $\begin{array}{l}\text { Total cleanliness score } \\
\text { Mean } \pm \text { SD }\end{array}$ & $p$-value \\
\hline \multirow[t]{2}{*}{ Tying system } & Chain $55.7 \%(\mathrm{n}=39)$ & $12.2 \pm 3.2^{\mathrm{a}}$ & $p<0.05$ \\
\hline & Grabner system $44.3 \%(\mathrm{n}=31)$ & $10.6 \pm 2.3^{\mathrm{b}}$ & \\
\hline \multirow[t]{3}{*}{ Stall dividers } & No dividers $42.9 \%(\mathrm{n}=30)$ & $12.5 \pm 3.1^{\mathrm{a}}$ & \\
\hline & Every second stall $14.2 \%(\mathrm{n}=10)$ & $11.4 \pm 4.0^{\mathrm{b}}$ & $p<0.05$ \\
\hline & Every stall $42.9 \%(\mathrm{n}=30)$ & $10.5 \pm 2.8^{\mathrm{b}}$ & \\
\hline \multirow[t]{3}{*}{ Divider design } & No dividers $42.9 \%(\mathrm{n}=30)$ & $12.5 \pm 3.1^{\mathrm{a}}$ & \\
\hline & Long $20 \%(\mathrm{n}=8)$ & $11.0 \pm 2.0^{\mathrm{b}}$ & $p<0.05$ \\
\hline & Short $80 \%(\mathrm{n}=32)$ & $10.6 \pm 3.4^{\mathrm{b}}$ & \\
\hline \multirow[t]{3}{*}{ Stall flooring } & Concrete $67.1 \%(n=47)$ & $11.6 \pm 2.3^{\mathrm{a}}$ & \\
\hline & Rubber mats $21.4 \%(\mathrm{n}=15)$ & $10.4 \pm 3.0^{\mathrm{a}}$ & $p>0.15$ \\
\hline & Wooden floor $11.5 \%(\mathrm{n}=8)$ & $12.6 \pm 4.0^{\mathrm{a}}$ & \\
\hline \multirow[t]{3}{*}{ Bedding } & No bedding $50 \%(n=35)$ & $11.5 \pm 2.8^{\mathrm{a}}$ & \\
\hline & Sawdust $7.1 \%(n=5)$ & $10.7 \pm 6.4^{\mathrm{a}}$ & $p>0.15$ \\
\hline & Straw $42.9 \%(n=30)$ & $11.5 \pm 3.0^{\mathrm{a}}$ & \\
\hline \multirow[t]{3}{*}{ Manure system } & Open gutter $42.9 \%(n=30)$ & $12.9 \pm 2.7^{\mathrm{a}}$ & \\
\hline & Slatted flooring $34.3 \%(\mathrm{n}=24)$ & $9.6 \pm 2.6^{\mathrm{b}}$ & $p<0.0005$ \\
\hline & No gutter $22.9 \%(\mathrm{n}=16)$ (traditional) & $11.6 \pm 3.5^{\mathrm{a}}$ & \\
\hline
\end{tabular}

a,b Means with different superscripts differ $(p<0.05)$

From the selected housing variables, only presence of stall dividers showed significant association to total cleanliness score in the statistical model $(p<0.05)$. The presence of dividers was associated with cleaner cows. Concerning thigh cleanliness, no association with the housing variables was found. However, the last variable to be removed in the statistical model was the presence of stall dividers $(p=0.17)$.

\section{DISCUSSION}

The majority of the cows (> $80 \%)$ were quite clean (score 1 and 2) on udder and belly. The udder of dairy cows is normally the cleanest body part because of being cleaned daily as a part of the milking routine (Veisser et al., 2004). However, in similar studies with cubicles (e.g. Ruud et al., 2010) around $95 \%$ of the cows were found to be quite clean. When looking at leg cleanliness, the proportion of cows with score 1 (clean) was relatively high $(23.4 \%)$ in the present study compared to other investigations like Ruud et al. (2010), but interestingly, when combining score 1 and 2 , the proportion of clean herds was actually lower. Also the proportion of herds with score 4 (very dirty) was higher than in other studies. A major concern is that more than $50 \%$ of the cows were scored as dirty (score 3 ) or very dirty (score 4 ) on the thigs and on the rear body part.

Concerning total cleanliness score, as much as $24.3 \%$ of the cows got a score of $>15$. These cows are actually unacceptable dirty, and the proportion of dirty cows was much higher than found in herds with cubicle housing (DeVries et al., 2012; Ruud et al., 2010; Schreiner and Ruegg, 2003). Generally, it is more challenging to keep cows clean in tie-stalls systems (Herlin et al., 1994). Still, it is both necessary and possible to introduce measures that improve the cow cleanliness in the herds surveyed in the present study.

Interestingly, the variation in cow cleanliness among herds in the present study was large, and in some of the herds the cleanliness scores were actually low, showing that these herds managed to keep the cows acceptably clean. Most farmers made use of simple homemade constructions, also with a large variation in stall design within herds. Still, the presence of stall dividers was found to be associated with significantly improved cow cleanliness 
in the statistical model. This finding nicely supports the common recommendations to use stall dividers (e.g. Agriculture Canada, 1981; EFSA, 2009; Ruud et al., 2015), but there is actually a lack of other scientific studies documenting the positive effect of stall dividers (Nygaard, 1979). The present study showed that the presence of stall dividers per se is of importance for cow cleanliness, whereas design and frequency of dividers seem to be of less importance.

When investigating stall design variables individually, overall cow cleanliness was found to be better using the Grabner tying system compared to the tying chain system. Unfortunately, the Grabner system is restricting the cow movements considerably and is therefore not allowed in some countries (LMD, 2004) due to animal welfare reasons. It is therefore questionable as a mean to achieve cleaner cows.

Also slatted floor covering the gutter was found to improve cow cleanliness, however, in several herds the resting space available for the animals was restricted and the cows were forced to use parts of the slatted floor area for lying. Design variables related to gutter design varied considerably from herd to herd as well as within herd, but were not recorded in the present study. Therefore, more detailed studies should be performed to give better information regarding construction issues.

The effect of stall flooring and type of bedding on cow cleanliness was not found. The use of bedding is commonly recommended to keep cows clean, however, in larger quantities than what was found in present study.

Cow cleanliness is often suggested as an indicator of herdmanship and management (Veissier et al., 2004). Herdmanship and management factors have surely influenced the cow cleanliness, especially when considering the large variation between herds, but these factors were neither identified nor an objective of the present study. Still, cow cleanliness could definitely be improved by optimizing management and daily routines.

\section{CONCLUSIONS}

We conclude that a large proportion of the cows were unacceptably dirty both on the legs, thigh and rear. The large variation between herds imply that cow cleanliness can be improved by optimizing the management routines, like use of bedding, and by making changes to the stall design, especially introduction of stall dividers.

\section{ACKNOWLEDGEMENTS}

The authors wish to thank all the participating farmers for their helpfulness during the study. The study was financially supported by the Norwegian HERD programme (grant ref. no. $332160 \mathrm{UU})$.

\section{REFERENCES}

Addinsoft. (2016). Addinsoft student package XLSTAT-Base solution. Paris, France: Addinsoft.

Agriculture Canada. (1981). Tie-stall dairy cattle housing. Publ. 1714.

Bergsten, C., \& Pettersson, B. (1992). The cleanliness of cows tied in stalls and the health of their hooves as influenced by the use of electric trainers. Prev Vet. Med., 13, 229-238. https://doi.org/10.1016/0167-5877(92)90038-H

DeVries, T. J., Arnoude, M. G., Barkema, H. W., Leslie, K. E., \& von Keyserlingk, M. A. G. (2012). Associations of Dairy cow behaviour, barn hygiene, cow hygiene and risk of elevated somatic cell count. J. Dairy Sci., 95, 5730-5739. https://doi.org/10.3168/jds.2012-5375

DG SANTE. (2017). Overview report Welfare of Cattle on Dairy Farms. Luxembourg: Publications Office of the European Union.

EFSA. (2009). Scientific report on the effects of farming systems on dairy cow welfare and disease. Report of the Panel on Animal Health and Welfare. Annex to the EFSA Journal, 1143, 1-284.

FAO, Regional office for Europe and Central Asia. (2012). The meat and dairy sector in Bosnia and Herzegovina. Preparation of IPART sector analyses in Bosnia and Herzegovina (Contract number 2010/256-560). Rome, Italy: FAO.

Gjestang, K. E. (1980). Driftsfunksjonelle undersøkelser av båsinnredning for mjølkeku [Investigations of the function of stalls for dairy cows] (Report No. 165). Ås, Norway: Institutt for bygningsteknikk, Norges landbrukshøgskole [Department of Agricultural Structures, Agricultural University of Norway].

Glavić, M., Zenunović, A., \& Budiša, A. (2017). The Production, Purchase and Processing of Milk in Bosnia and Herzegovina. Agro-knowledge Journal, 18(3), 187-198.

Hauge, S. J., Kielland, C., Ringdal, G., Skjerve, E., \& Nafstad, O. (2012). Factors associated with cattle cleanliness on Norwegian dairy farms. J. Dairy Sci., 95, 2485-2496. https://doi. org/10.3168/jds.2011-4786

Herlin, A. H., Magnusson, M., \& Michanek, P. (1994). Faecal contamination of the lying area for dairy cows in different housing systems. Swedish J. Agric. Res., 24, 171-176.

Hultgren, J., \& Bergsten, C. (2001). Effects of a rubber-slatted flooring system on cleanliness and foot health in tied dairy cows. Prev. Vet. Med., 52, 75-89. https://doi.org/10.1016/ S0167-5877(01)00237-9

Jovović, V., Rogić, B., Važić, B., Bøe, K. E., Ruud, L. E., \& Erbez, M. (2014). Examination of certain parameters affecting dairy cows' welfare in Bosnia and Herzegovina. In D. Kovačević (Ed.) Book of proceedings: Fifth International Scientific Agricultural Symposium „Agrosym 2014“ (pp. 854858). Retrieved from http://www.agrosym.rs.ba/agrosym/ agrosym_2014/documents/PROCEEDINGS_2014.pdf 
LMD (Norwegian Ministry of Agriculture and Food). (2004). Forskrift om hold av storfe [Regulations on keeping cattle]. FOR-2004-04-22-665.

Neja, W., Bogucki, M., Jankowska, M., \& Sawa, A. (2016). Effect of cow cleanliness in different housing systems on somatic cell count in milk. Acta Vet. Brno., 85, 55-61. https://doi. org/10.2754/avb201685010055

Nygaard, A. (1979). Omgivelsesstudier i hus for mjølkeproduksjon [Environmental studies in houses for milk production]. In Meldinger fra Norges Landbrukshøgskole, 58(19) (pp 64). Ås, Norway: NLH.

Official Gazzette of BiH. (2009). Zakon o zaštiti i dobrobiti životinja [The law on animal welfare and protection]. No. 25/09.

Official Gazzette of RS (Republic of Srpska), Bosnia and Herzegovina. (2016). Program uzgoja goveda u republici Srpskoj za period 2016-2021. godine [Program of cattle breeding in Republic of Srpska for period 2016-2012]. No. 72/16.

Popescu, S., Borda C., Diugan, E. A., Spinu, M., Groza, I. S., \& Sandru, C. D. (2013). Dairy cows welfare quality in tie-stall housing system with or without access to exercise. Acta Veterinaria Scandinavica 55, 43-54. https://doi. org/10.1186/1751-0147-55-43

Reneau, J. K., Seykora, A. J., Heins, B. J., Endres, M. I., Farnsworth, R. J., \& Bey, R. F. (2005). Association between hygiene scores and somatic cell scores in dairy cattle. J. Am. Vet. Med. Assoc., 227, 1297-1301. https://doi.org/10.2460/ javma.2005.227.1297

Rogić, B., Vazić, B., Jovanović, S., Stamenković, R. M., Savić, M.,
\& Ravić, I. (2011). Investigations of variability of morphometric characteristics in busa and gatacko cattle in order to preserve autochthonous genome. Vet. Glasnik, 65(1-2), 51-69. https://doi.org/10.2298/VETGL1102061R

Ruud, L. E, Bøe, K. E., \& Østerås, O. (2010). Risk factors for dirty dairy cows in Norwegian freestall systems. J. Dairy Sci., 93, 5216-5224. https://doi.org/10.3168/jds.2010-3321

Ruud, L. E, Stokke, T., Bøe, K. E., Hettasch, T., \& Skjølberg, P. O. (2015). Hus for storfe - Norske anbefalinger [Cattle housing - Norwegian recommendations]. Ås, Norway: Tine.

Schreiner, D. A., \& Ruegg, P. L. (2003). Relationship between udder and leg hygiene scores and subclinical mastitis. J. Dairy Sci., 86, 3460-3465. https://doi.org/10.3168/jds. S0022-0302(03)73950-2

Simensen, E., Østerås, O., Bøe, K. E., Kielland, C., Ruud, L. E., \& Næss, G. (2010). Housing system and herd size interactions in Norwegian dairy herds; associations with performance and disease incidence. Acta Vet. Scand., 52, 1-9. https://doi. org/10.1186/1751-0147-52-14

Veissier, I, Capdeville, J., \& Delval, E. (2004). Cubicle housing systems for cattle: comfort of dairy cows depends on cubicle adjustment. J. Anim. Sci. 82, 3321-3337. https://doi. org/10.2527/2004.82113321x

Zurbrigg, K., Kelton, D., Anderson, N., \& Millman, S. (2005). Tie-stall design and its relationship to lameness, injury, and cleanliness on 317 Ontario dairy farms. J. Dairy Sci., 88, 3201-3210. https://doi.org/10.3168/jds.S00220302(05)73003-4 